\title{
Dystopias of Reproductive Nightmare: The Ice People and The Children of Men
}

\author{
ÖĞR. GÖR. NIĞMET ÇETiNER*
}

\begin{abstract}
Maggie Gee's The Ice People (1998) and Phyllis Dorothy James's The Children of Men (1992) are two dystopian novels introducing societies afflicted with infertility because of scientific advancements that have spun out of control. In the novels, science gives way to countless innovations that provide help and comfort in daily life. However, it falls short of determining the exact reason and finding any solution for the problem of infertility. The root cause for this calamity is suggested to be the anthropogenic activities deteriorating nonhuman environments and causing reproductive health problems. Set in Britain in 2050, Gee's The Ice People portrays a world at the onset of a new ice age. Picturing a world after the global warming during which fertility rates decline dramatically, the novel presents a new type of human, techfixes, the children born through artificial conception, owing to the developments in science and technology. P. D. James describes a world where people abruptly become infertile in 1995, which she calls Year Omega in the novel. Mass infertility which threatens the existence of the humankind results in violence and cruelty against the remaining aging population inflicted by the tyrannical regime that never faces resistance from people. In line with this, the aim of this study is to analyze The Ice People and The Children of Men as works of dystopian fiction describing the ramifications of the misuse of science and technology, and the anthropogenic imprint on the nonhuman environment, which comes out as reproductive inability in human beings.
\end{abstract}

Keywords: Maggie Gee, P. D. James, infertility, dystopia, nonhuman environments

\section{ÜRE(YEME)ME KÂBUSU DİSTOPYALARI: THE ICE PEOPLE VE THE CHILDREN OF MEN Öz}

Maggie Gee'nin The Ice People (1998) ve Phyllis Dorothy James'in The Children of Men (1992) adlı romanları kontrolden çıkan bilimsel gelişmeler sebebiyle kısırlık sorunuyla karşı karşıya kalan toplumları anlatan distopik romanlardır. Bu eserlerde bilim, günlük hayatta yardım ve konfor sağlayan sayısız yeniliğin yolunu açar; ancak kısırlık sorununun kesin sebebini belirleyemediği gibi ona çözüm de sunamaz. Bu sorunun temelinde yatan sebep, doğal çevreyi kirleten ve üreme sağlığı sorunlarına yol açan beşerî aktivitelerdir. Gee'nin 2050 İngiltere'sini konu alan The Ice People adli eseri ise yeni bir buzul çağının başlangıcını tasvir eder. Küresel ısınmayla birlikte doğurganlık oranının dramatik bir biçimde düştüğü bir dünyayı resmeden roman, bilim ve teknolojideki ilerleme sayesinde yapay döllenme yoluyla doğan, romanda "techfix" olarak adlandırılan çocuklardan bahseder. P.D. James, Omega Yılı olarak adlandırdığı 1995 yılında insanların aniden üreme yeteneklerinin ortadan kalktığı bir dünyayı betimler. İnsan varlığını tehdit eden kitlesel kısırlık kısırlık sonucunda, geride kalan yaşlı nüfus, kimsenin karşı çıkmadığı baskıcı rejimin şiddet ve acımasızlığına maruz kalır. Bu çalışma, The Ice People

\footnotetext{
* Kastamonu Ün. Yabancı Diller Yüksekokulu, ncetiner@kastamonu.edu.tr, orcid: 0000-0003-0229-6338 
ve The Children of Men romanlarının insanlarda üreme sorunu olarak ortaya çıkan bilim ve teknolojinin kötüye kullanılması konusunu ve doğadaki insan kaynaklı sonuçlarını vurgulamaları açısından incelemeyi amaçlamaktadır.

Anahtar sözcükler: Maggie Gee, P. D. James, kısırlık, distopya, doğa

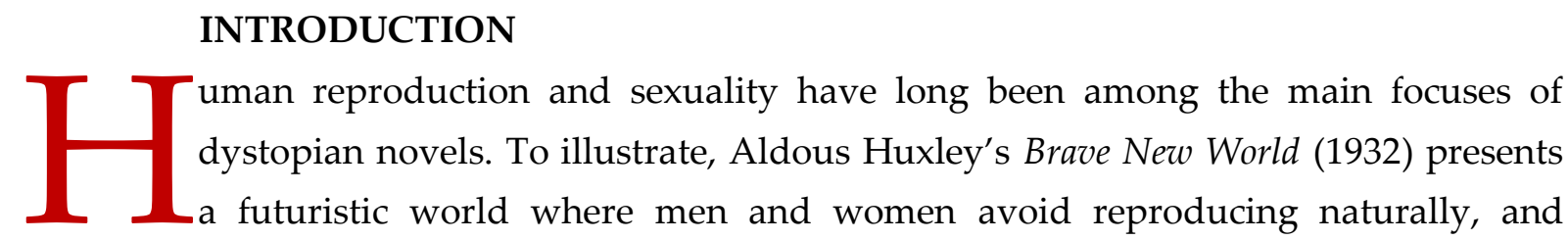
women do not become pregnant. Instead, genetically engineered, and mass-produced embryos are grown to be the members of different castes destined to perform various duties, such as menial labor. By doing so, the state intends to remove strong emotions, desires, and human relationships from the society. Furthermore, people distance themselves from the traditional concepts of maternity and family. Huxley's novel has inspired several other works including George Orwell's 1984 (1949). In 1984, London in the nation of Oceania, is under the totalitarian control of the Party, which banishes free thought, sex, and the expression of individuality. In this society, people are always under constant government surveillance even at home, and they are not allowed to fall in love or have sex. These famous examples effectively display the reproductive, political and social issues in the dystopian states.

There are dystopian novels in which reproduction is more in the foreground. Either a problem of overpopulation or a concern about an abrupt decrease in the population is present in such novels. To illustrate, John Brunner describes an overcrowded world in the year 2010 in his almost prophetic book entitled Stand on Zanzibar (1968). Brunner's work foreshadows what might happen to the surplus population and the natural environment which has been destroyed with the aim of providing resources to maintain life once the world is overpopulated. Moreover, the anthropogenic impact of pollution and chemical spills in Margaret Attwood's The Handmaid's Tale (1985) leads to the decline of fertility rates resulting in the oppression of fertile women. Atwood's Oryx and Crake (2003) introduces a mad scientist who thinks that the core cause of human suffering is overpopulation. Thus, he works to create pills that render people infertile, and he spreads a plague through these pills killing a great proportion of the human population. Crake is one of those "[...] brave (or psychotic) individuals [...] depicted as taking matters into their own hands for a variety of reasons" in dystopian novels (Grech et al., 2015, p. 27). In the novels concerned with overpopulation; totalitarian governments, individuals, or corporations attempt to reduce the population by removing the surplus population or interfering with reproduction. Moreover, in the novels depicting a world in which human population declines dramatically driving humanity to near extinction, and humans try to find ways to prevent the demise of their species using technoscience or authoritarian power and control. In a similar vein, Gee's The Ice People and James's The Children of Men are dystopian novels introducing societies that suffer seriously from declining fertility rates, the reason of which are not given clearly in either novel, but are hinted to be humaninduced. The horror concerning the risk of the extinction of human species through infertility as 
well as individual, collective, and state behaviors in a time of anthropogenic chaos is the focus of this study.

\section{MAGGIE GEE'S THE ICE PEOPLE AND P. D. JAMES'S THE CHILDREN OF MEN AS NARRATIVES REFLECTING THE ANTHROPOGENIC IMPACT AND ITS CONSEQUENCE; INFERTILITY ${ }^{1}$}

\section{The Ice People}

The new ice age takes over the world after the global warming in Maggie Gee's The Ice People that serves as a cautionary tale about the not-so-distant future of the world and humanity. The global ecological crisis is coupled with another dreadful catastrophe accelerating the extinction of homo sapiens. Fertility rates decrease so dramatically that reproduction is almost impossible without the help of reproductive technologies. Moreover, the dramatic decrease in male fertility as well as global ecological catastrophe alienates men and women adding up to the growing population problem. Reckless exploitation of the ecosystems and slaughtering fellow species are other factors that contributes to humans' inability to make babies in the novel $(2016,99)$. The Ice People highlights the impending problems humans and the nonhuman will face in near future. It perfectly reflects the worsened conditions in the continuation of the Age of Man during which humans act as the dominant geological force steering themselves and Earth towards their demise.

The Ice People introduces the imagined condition of the anthropocentric society in Britain and around the new world which is transformed with the sudden climate change during a time of an ecological crisis. It not only reflects the state of Earth or Britain as a microcosm of the planet, before, during and after a global environmental catastrophe, but it also realistically meditates on how social conditions would change under these circumstances. To illustrate, the issue of climate refugees migrating from their native countries to the countries less affected by climate change in search of a haven will grow more and more problematic as a side effect of the global warming or a subsequent ice age, as similarly described in Gee's work:

... environmental degradation can generate migration flows. Global warming could, in particular, lead to major forced displacements. This will result principally from rising sea levels, but will only progressively manifest itself over the coming centuries, with the exception of the flooding of certain islands. The increase in droughts and meteorological disasters predicted by climatic models will also have impacts in terms of migrations, but these will remain regional and short-term, and are at present difficult to estimate. (Piguet, 2008, p. 8)

Furthermore, the horrific consequences of a human-induced global ecological crisis with regards to nonhuman animals are mirrored in the novel. Likewise, the social relations of the individual characters reflect the situation of the wider society. It can be deduced from the novel that science and technology, when not used for the good of the whole (for the good of the humans as well as the nonhuman), will eventually spiral out of control and destroy everything. As Düzgün similarly notes, "in The Ice People and The Flood, the author claims that science and technology aim

\footnotetext{
${ }^{1}$ References to The Ice People will be given with chapter numbers and references to The Children of Men will be given with page numbers.
} 
to provide health, comfort and wealth; but uncontrolled use of scientific and technological tools has destructive effects both on nature and people of all milieux" (2018, p. 61). The exploitation of the material world through science and technology results in deadly viruses, drought, global warming, a subsequent ice age, the rise of sea levels, biodiversity loss and pollution, all of which are reflective of "the magnitude of the effects that humans have had on the planet" (Kuznetski and Alaimo, 2015, p. 138). Similarly, as Victoria Bilge Yllmaz and Raushan Kamalova note, "nature" is "grounded in the total integration of nature and human beings" (2019, p. 218). Accordingly, human agency is not separate from nature and humans are not supreme beings that act upon the nonhuman. The nonhuman is indeed not "the inert, external matter of the world" as it was formerly thought to be (2015, p. 138). When the transcorporeal human body becomes infertile, as the two novels central to this study picture, the ultimate interconnection of the human body with the nonhuman is manifest. In other words, the negative anthropogenic changes on Earth find their reflection in the human body.

The initial effect of the anthropogenic impact on Earth in the novel is global warming. The early childhood and adolescence of the protagonist, Saul, who was born in 2005 during the period known as "the Tropical Time" coincides with the beginning of the global warming. Saul, his family, and their country experience the climate crisis in many ways. To illustrate, even "[...] watering [their] garden from the tap was a crime" because of the water shortage (Chapter 2). Moreover, with rising sea levels due to the heat and thawing of the glaciers, some parts of the white Dover cliffs collapse into the sea. Climate refugees migrate from the countries that suffer from the global warming to take refuge in Britain. Likewise, as another side effect of the global warming, a number of unknown diseases emerge. In Saul's early twenties, a plague, a kind of new Ebola causing "haemorrhagic sleeping sickness," kills people in their cars by causing excessive bleeding (Chapter 2). The civil order collapses, the streets are no longer safe, and the police force has been weakened and ineffective, according to Samuel, Saul's father. However, teenagers do not concern themselves with what is going on in their country: "We ate in the sun; we danced in the sun. [...] When the evening came, we mobbed the streets" (Chapter 2). In his youth, Saul is also nonchalant about the global warming, the viruses that run wild, and the deteriorating situation of the government and the collapse of the civil order: "When civil order broke down, over the next few years, I stayed optimistic. Who needed governments? If you were young, you were self-reliant. The plagues passed me by, though I lost several friends. [...] I didn't let the newscasts upset me" (Chapter 2). Saul carries on with his account by describing the changing fashions and social relationships of the time alongside the climate change. Androgyny is fashionable among both men and women. Therefore, they shave their heads and bodies because "[...] hair was suspect, for it signaled gender" (Chapter 2). Although men and women all look similar, they avoid each other: "Almost everything we did was segged. Girls with girls, boys with boys, great droves of animals bypassing each other, eyes darting across, wild in neon, jostling, signaling, twisting through the night, two big streams that couldn't make a river" (Chapter 2). They name this phenomenon "segging" deriving from the word "segregation." The members of each sex prefer to be with the 
members of the same sex, and homosexuality becomes prevalent. However, "segging" is not the only reason behind the declining population.

As the story unfolds, it is gathered that after the global warming reaches its pinnacle, it is followed by a new ice age. Saul and other fellow humans are confronting what Slavoj Žižek calls the "apocalyptic zero-point" of the global capitalist system (2010, p. x). Quite a few of the "'four riders of the apocalypse,'” dubbed as "the ecological crises, the consequences of biogenetic revolution, imbalances within the system itself (problems with intellectual property; forthcoming struggles over raw materials, food, and water), and the explosive growth of social divisions and exclusions" are manifest in the novel (Žižek, 2010, p. x). Human-induced climate change that is the distinguishing characteristic of the Anthropocene has profound effects on every aspect of human life in the novel (Crutzen, 2002, p. 23). The Anthropocene is the unofficial name of the current geological epoch first proposed by Paul Crutzen in 2001 and popularized by Eugene F. Stoermer (Forke and Wizemann, 2012, p. 70). This epoch is suggested to have started during the time when James Watt's designed the steam engine which later resulted in increasing fossil fuel combustion and pollution (Crutzen, 2006, p. 13). According to the Antropocene theory, humans became the "new telluric force which in power and universality may be compared to the greater forces of earth," that has profound impact on the surface of Earth (as cited in Crutzen, 2002). As there is an intra-action between human and nonhuman bodies and human body is "transcorporeal", humans are equally affected by the change they caused in their surroundings (Alaimo, 2010, p. 22). In the novel, humans experience the effect of this impact as climate change. In addition to causing an irreconcilable gap between men and women, the ecological crisis is suggested to be the main reason for the dramatic decline in fertility rates. Regarding the relation between climate change and fertility, according to the new research carried out in 2018, it is concluded that "[h]eatwaves reduce male fertility and sperm competitiveness [in bees], and successive heatwaves almost sterilize males"' (Sales et al., 2018, p. 1). The results of the experiment on bees prove that the global warming plays a significant role in biodiversity loss that would influence the lives of the humans in the same way as the nonhuman since "insects play a crucial role in pollinating our crops and stabilizing many of the food webs and ecosystems that we rely on" (Ferreira, 2018, para. 1). In similar fashion, based on the research executed by UCLA Institute of the Environment and Sustainability, it is found out that high temperature affects human reproduction adversely reducing the possibility of conception and the situation is expected to worsen in parallel to the severe global warming (Barreca et al., 2018, p. 1269). In line with these studies, it can be gathered from the novel that the anthropogenic global warming is one of the multiple impetuses behind the reproductive problem humanity faces. In other words;

Although the novel does not draw a specific connection between global warming and infertility, it is implicitly suggested that the collapse of the planetary ecosystems, the depletion of natural food resources and water shortages have inevitably led to decrease in the fertility levels. As the ecological balance deteriorates, reproductive health deteriorates, too [...]." (Sepetoğlu, 2014, p. 36)

In the novel it can be observed that human body is intermeshed with the more-than-human world, and it is changed by global warming as well as the ensuing drought and famine which 
render it sterile. Therefore, the novel presents a picture of countless men who cannot have children no matter how much they want to because their sperm is semi-fertile and women do not want to conceive children by them: "Yet none of these men could reproduce, because they had no women to carry their babies. And probably [their] sperm was useless" (Chapter 11). Those with fertile sperms can have children if they persuade a woman to engage in sexual intercourse. Saul is one of those men. He meets Sarah, who, like Saul, has traditional ideas about getting married and settling down as opposed to a great proportion of the society that incline towards open relationships. The couple even tries to have children. However, Sarah cannot conceive a child because Saul's sperm is semi-fertile as he learns after getting tested. Therefore, they must resort to reproductive technologies to have a "techfix" baby that is conceived through medical intervention on sperm and ova in a laboratory environment. It can be discussed that Gee's projection about the human reproduction in the Anthropocene is factual since the scientists express how the Anthropocene has a profound impact on human health, and humans are becoming more dependent on the assisted reproductive technologies to have children and to continue their lineage (Gluckman, 2020, pp. 304310).

Saul and his techfix son, Luke, embark on an odyssey to Africa. Luke becomes "a sign of hope" for both humanity, and for Saul in terms of "genetic survivalism" since "Saul seeks to save Luke in order to preserve his lineage" (Johns-Putra, 2018, p. 93). To save Luke from the cannibalistic people, Saul leaves Briony, a member of the Wicca, a women's commune, and Sarah's friend behind. At this point, he realizes that he is not different from or superior to the nonhuman, but he is a living being struggling to preserve his genetic traits and pass them onto future generations: “But now, when I am so much older and colder, I see I wasn't a hero, or a villain, or any of the things they say in stories - but merely one tiny unit of biology, stopping at nothing to save his genes" (Chapter 18). Luke is not just a vessel that carries the genetic traits of Saul; he is also "the figure of the child" who is "a particularly emotive shorthand conceal[ing] a collective angst about bio spheric destruction," and "this anxiety is exacerbated by the ethical dilemmas that underlie our obligations not just to future humans but to nonhuman species" (Johns-Putra, 2017, p.1). Ironically, while the nonhumans that are a part of nature are on the brink of extinction because of the human-induced destruction of the biosphere, with the exception of some animals such as cats and wolves, the Doves, as part of technology can replicate and evolve doing what humans currently cannot. Even more surprisingly, they are capable of reproduction without external intervention.

The main reason behind infertility and the subsequent decrease in human population is not openly indicated in The Ice People. However, one can assume that it is not nuclear/bioterrorism or "an accidental and involuntary iatrogenic event" (Grech et al., 2012, p. 26), but rather the anthropogenic climate change itself. In this respect, the novel draws a correlation between the global catastrophe and infertility. It is made apparent that human body and the nonhuman are entangled. Therefore, infertility seems to be the ultimate penance to atone for destroying the ecological balance. Anthropocentrism and androcentric attitudes coupled with the utilization of science and technology with disregard to ethical responsibility have the potential to destroy 
humanity along with the nonhuman. The author renders human exceptionalism as a misconception through the main character, Saul, who represents the whole humanity. The novel bears the warning that the anthropocentric mind-set and the disregard for the nonhuman will ultimately drive the humankind to the brink of extinction.

\section{The Children of Men}

Depicting another post-apocalyptic world, P. D. James's The Children of Men starts as a journal narrated through the protagonist's perspective. The owner of the journal is Theodore, or Theo, an Oxford don and the cousin of Xan Lyppiatt, the dictator and the "the Warden of England." Since 1995, the year that comes to be known as the Year Omega, people start living a horrible nightmare. They experience mass infertility arising from an unknown reason. Theo describes the effects of this adversity on the human body in his journal. The first-person narration and the parts of the book written in the form of a journal make the events more associable and the characters more relatable.

Humans face an abrupt onset of mass infertility. They feel angry and humiliated because they cannot find the reason. As the story unfolds, it is hinted that the cause of this almost Biblical catastrophe is the dramatic increase in human population and human-induced activity leading to pollution. While the population ages and declines rapidly, it generates various other problems. Xan Lyppiatt, the self-appointed Warden of England, and his council take drastic measures to keep the remaining population under control. Their actions are met with complacency because of lack of hope for future generations. On the other hand, Theo, the cousin to the Warden, helps a group of dissidents with the intention of revolting against Xan's dictatorship to save the only baby to be born in decades. The baby is the humanity's last hope to survive. James introduces a world where over-population together with science and technology which are used solely for humans' comfort drive the species to the brink of extinction. The novel implicitly gives the message that it will not be only the more-than-human world suffering from the consequences of humans' lethargy, but the humankind will the one to be harmed the most.

The totalitarian control of Xan that takes root in the afflicted societies abuses the remaining population, putting the poor and able-bodied to the service of the rich and the privileged. In other words;

The Children of Men clearly represents some of the dominant anxieties of the early 1990s: the burden of an increasingly ageing population (a ritual known as the "quietus" forces the old and infirm to commit suicide in group drownings); a concern that the use of modern chemicals in everyday life might be causing fertility problems; anxiety about the treatment of immigrants; the evolution, on the one hand, of a Thatcherite wealthy and powerful elite and, on the other, of a disenfranchised population easily manipulated by that elite. (Horner, 2014, p. 40)

As the population ages and the number of able-bodied individuals decreases, the State uses Sojourners, the Omegas imported to Britain from poor countries, to serve the members of the government or other privileged people. They are used for menial labor "to do [their] dirty work, clean the sewers, clear away the rubbish, look after the incontinent, the aged" (James, 1994, p. 84). 
They constitute the most exploited part of the population as they receive no protection from the government and have no rights. They are pressed into service until they reach the age of sixty, when they are deported.

Xan is the person who benefits from people's fatalistic and broken state of mind. Getting the support of the council, he creates the illusion of democracy while, in fact, he is a tyrant with draconian ideas about keeping his power until the very end. Xan and the Council are powerful because there is no one to resist them as people are broken by the idea of having no progeny, no future generations to which they can leave their legacy, and they do not have the will to resist the dictatorship. It does not matter for them how or by whom they are governed if they live their remaining days free from fear, want, or boredom (p. 129). They no longer want to have sex or fall in love because there is no possibility of having an offspring. To put in another way, they have a "hollow-sexual life" (Kaur, 2016, p. 197). By the order of the Warden, state-funded pornography shops are opened to stimulate people and encourage them to have sexual intercourse in order not to miss any chance for the conception of children. Suicide rates increase in 2008 when the Omegas are tested to find fertile sperm because people completely lose hope for having any future generations. Xan and the Council take drastic measures to keep their established system working through the control of the remaining population.

In accordance with the rules, family members of a young person who commits suicide are forced to pay fines. Moreover, the closest relatives of the incapacitated and dependent old citizens are paid a large pension in order to encourage the old population that are regarded a burden for the remaining able-bodied members of society to commit suicide. The Council and the Warden continue to misuse their power and influence with the Quietus which is a kind of mass suicide ritual for the old whose family members get a handsome pension from the State after their elderly commits suicide. To his horror, Theo learns that not all the people attending the Quietus are present voluntarily contrary to popular opinion. Additionally, there is another rule that forbids the Omegas from emigrating because they are the potential workforce for the elite. The penal colony on the Isle of Man, "to which all those convicted of crimes of violence, burglary or repeated theft are now banished," is another dreadful idea of the Council (14). Xan assures citizens that they are going to live the rest of their life crime-free while setting up the penal colony. However, it does not turn out to be so favorable for the inmates on the Isle. They are severely punished for the crimes they are accused for, and execution is the only punishment when inmates try to escape.

The magnitude of the disaster described in the novel is so great that even the sperm stored for the future use in artificial insemination loses the ability to fertilize ova. James does not give an explicit explanation concerning the reason for the universal infertility. However, it can be gathered from Theo's remarks that high human population polluted the planet accelerating the Anthropocene, which in turn changed human corporeality causing the mass infertility. The writer's association of human population with pollution, therefore with the acceleration of the Anthropocene, is quite accurate. As Paul J. Crutzen expresses, there is a strong link between population growth and the exhaustion of Earth's resources. In his words, “[d]uring the past three centuries, the human population has increased ten-fold, to more than six billion, and is expected to 
reach 10 billion in this century. As a result, 30-50\% of the planet's land surface is now exploited by humans" (2009, para. 1). Humans, as the new telluric force causing massive changes on Earth's surface such as soil erosion, acid precipitation and global warming, pollute the planet heavily with plastics and toxic matter. The use of plastics increased especially after the Industrial Revolution since plastics are heavily utilized in manufacturing. When humans are done with the objects made of plastic, they dump their plastic waste including "pharmaceuticals, personal care products, food additives, natural and synthetic hormone, and plastic debris in micro and nano range, among the others [...] to the environment," and the plastics that accumulate in food and water enter human bodies through consumption and decrease sperm quality (D'Angelo and Meccariello, 2021, p. 1). Furthermore, they lead to the feminization of male fetuses (Liboiron, 2013, p. 141). Humans have been ignoring the fact that human body is permeable, and it is in continuous intra-action with other matter. However, the intra-action between human body and the nonhuman such as plastics and technological devices proves the fact that agency does not solely belong to humans and, therefore, it requires "the repositioning of the human among the nonhuman actants" (Sanzo, 2018) and the need for seeking a new, flat ontology equalizing all matter. Moreover, it establishes evidence for the fact that human body is transcorporeal, and humans are "always intermeshed with the more-than-human world" that makes the matter of human body entangled with the nonhuman environments (Alaimo, 2008, p. 238).

\section{CONCLUSION}

It is suggested in both novels that infertility is sperm-based for the most part. It shows parallelism with the condition in today's world. The number of sperms declined fifty percent in the past fifty years, and it is expected that, by 2045, half of the male population will have no fertile sperm (Luján et al., 2019, p.1). According to another study published in 2010, "an estimated 48.5 million couples are experiencing infertility worldwide, and data from 2015 suggests that at least 30 million people who produce sperm experience infertility" (Malinda, 2021, para. 2). The posthuman condition, being immersed in and intertwined with technology in day-to-day life, is one of the many reasons that cause sperm infertility. For instance, according to a study shared the Virtual SLEEP 2020 meeting, digital devices such as mobile phones and laptops used at night affect sperm quality ("Late-night use of gadgets," para. 2). The novels emphasize "the embeddedness of the human being in not just its biological but also its technological world" serving the purpose of posthumanism in "decentering of the human by its imbrication in technical, medical, informatics, and economic networks is increasingly impossible to ignore," as Cary Wolfe states (2010, p. xv). The concept of human as a rational supreme being is refuted and the necessity to understand the power of matter over human corporeality and interdependence between humans and the nonhuman are underlined in this perspective. Therefore, in contrast to the Renaissance concept of humanism, it could be argued that "humans have always been posthuman," interacting and intraacting with their environment (Ferrando, 2016, pp. 243-256).

The posthuman condition is manifest in both novels as humans become more dependent on the technology that leads to their extinction. In The Ice People, humans need reproductive 
technologies to have techfix babies in order to reproduce. In The Children of Men, they try to find fertile sperms or ova through semen testing, and gynecological examinations which they enforce on bodily perfect Omegas. A similar situation is observable in today's world. The Covid-19 pandemic, which stems from the human-induced ecological imbalance and has the potential to threaten the existence of humanity, has increased the dependence on technology. Adults rely on digital technology to work and children to access education from their homes. In addition, the pandemic forces humanity to find a solution to end it through science. Utilization of robot technology and AI plays an important role by minimizing human interaction and the possibility of getting infected in enclosed environments. Supporting this, Rosi Braidotti presents her idea about the Covid-19 pandemic and how it reinforced the posthuman condition:

The COVID-19 pandemic is a man-made disaster, caused by undue interference in the ecological balance and the lives of multiple species. Paradoxically, the contagion has resulted in increased use of technology and digital mediation, as well as enhanced hopes for vaccines and biomedical solutions. It has thereby intensified humans' reliance on the very high-tech economy of cognitive capitalism that caused the problems in the first place. This combination of ambivalent elements in relation to the Fourth Industrial revolution and the Sixth Extinction is the trademark of the posthuman condition. (2020, p. 465)

In the novels, science and technology fail the humanity because they cannot find out the cause of the mass infertility and "[they] did not detect Julian's or the priest's fertility mainly because it was the role of the technology to rule out the possibility of 'imperfect' bodies be used as fertile vessels" (Marques, 2013, p. 46). In P.D. James' words:

Western science has been our god. [...] We have had twenty-five years and we no longer even expect to succeed. Like a lecherous stud suddenly stricken with impotence, we are humiliated at the very heart of our faith in ourselves. For all our knowledge, our intelligence, our power, we can no longer do what the animals do without thought. No wonder we both worship and resent them. (p. 7)

Cherishing science and technology and celebrating the domination of nature is a recent mindset. It is argued that "the most popular and enduring [trend] is firmly within the Western liberal current: the historically very recent idea that the increase of human power over the rest of nature through the growth of knowledge and industry is possible and desirable [...]" (MacLeod, 2013, p. 230). Works of science fiction such as The Children of Men and The Ice People serve as a warning, and they reveal the consequences of the Western liberal current concerning the fact that anthropocentric attempts to dominate nature and to excel in science and technology without heeding the tell-tale signs of the ecological collapse stemming from the climate change are doomed and the humankind will face an existential risk. Bearing in mind that the exploitation of the nonhuman world prompts an ecological crisis that will have disastrous consequences concerning human societies as much as the nonhuman, humans should have "a strong understanding of ethical responsibility to our fragile planet, [and] environmental literature confronts these challenges and promises to raise a local and global awareness" (Kaya, 2021, p. 31). In this sense, the novels "serve as modern parables that warn against excessive hubristic overreach in our chase for 
posthuman changes that may seem to be improvements but actually hamper or hinder humanity, in this case, through infertility" (Grech et al., 2015, p. 48).

In short, The Ice People and The Children of Men, as two works of science fiction, question the present condition of Earth and humanity. They criticize the indifferent attitudes maintained by humans in terms of the adversities they may face in the future. They are cautionary parables about the impending end of humanity together with the environment and nonhumans when science and technology solely serve the comfort and the pleasure of the human species instead of providing ways to live in symbiosis with the nonhuman. The present problems confronted by human societies and their fellow beings are projected into the future in an exaggerated way to exhibit the great dangers ahead stemming from human decisions, indifference, and self-indulgence. The ultimate outcome of this indifference and self-interest is infertility which will drive human species to the brink of extinction. Therefore, these novels call forth a rethinking of human and nonhuman relationships in an ethical way while utilizing science and technology.

\section{REFERENCES}

Alaimo, Stacy (2010). Bodily Natures: Science, Environment, and the Material Self. Indiana: Indiana University Press.

--- (2008). "Trans-corporeal feminisms and the ethical space of nature." Material Feminisms (eds. Stacy Alaimo and Susan Hekman), Indiana University Press, 237-264.

Barreca, Alan, et al. (2018). "Maybe Next Month? Temperature Shocks and Dynamic Adjustments in Birth Rates." Demography 55, 4, 1269-1293. https://doi.org/10.1007/s13524018-0690-7

Braidotti, Rosi (2020). "We" Are in This Together, But We Are Not One and the Same." Journal of Bioethical Inquiry 17, 4, 465-469. https://doi.org/10.1007/s11673-020-10017-8

Crutzen, Paul (2009). "Can We Survive the "Anthropocene" Period?" Project Syndicate. Retreived June 5, 2021, from https://www.project-syndicate.org/commentary/can-we-survive-the-anthropocene--

period?utm_term=\&utm_campaign=\&utm_source=adwords\&utm_medium=ppc\&hsa_acc=

$1220154768 \&$ hsa_ cam $=12374283753$ \&hsa_grp=117511853986\&hsa_ad=49956780219 \&hsa_src=g\&hsa_tgt $=$ dsa-19959

388920\&hsa_kw=\&hsa_mt=b\&hsa_net=adwords\&hsa_ver=3\&gclid=CjwKCAjwp_GJBhBmEi wALWBQ wpm

7h0TRZEZRPpfRBDDqWyqGem6hpcShrIyBL_7G4pSUQihM6PY5RoC-fMQAvD_BwE.

--- (2006). “The 'Anthropocene'”. Earth System Science in the Anthropocene. (eds. Eckart Ehlers and Thomas Krafft), Springer, 13-18.

--- (2002). “Geology of Mankind.” Nature 415, 23.

D'Angelo, Stefania and Meccariello, Rosaria (2012). "Microplastics: A Threat for Male Fertility." International Journal of Environmental Research and Public Health, 18, 5, 1-11. DOI: 10.3390/ijerph18052392 
Düzgün, Şebnem (2018). "Maggie Gee'nin The Ice People ve The Flood Adlı Eserinde Bilim ve Toplum." Sosyal ve Beşeri Bilimler Araştırmaları Dergisi 19, 43, 61- 75.

https://dergipark.org.tr/tr/pub/sobbiad/issue/39955/504

Ferrando, Francesca (2016). "Humans Have Always Been Posthuman: A Spiritual Genealogy of Posthumanism." Critical Posthumanism and Planetary Futures (eds. Banerji Debashish and Marakand R. Paranjape), Springer, 243-256.

Ferreira, Becky (2018) “Climate Change May Practically Sterilize Male Insects." Vice. Retrieved, February 2, 2021, fromhttps://www.bbc.com/news/science-environment46194383\#: :text=Heatwaves\%20can\%20damage \%20the\%20sperm, sterile\%2C\%20according\%20to\%20new\%20research. \&text=Further\%20work\%20could $\% 20$ shed \%20light, in\%20insect $\% 20$ populations $\% 2$ C\%20say\%20researchers.

Forke, Sven and Wizemann, André (2012). The aquatic climate archive: tracking the rise and fall of ancient civilizations. Lessons from the past, for the present and the future? [Paper Presentation]. Recent Impulses to Marine Science and Engineering, Bremen, Hamburg, Lübeck, Germany. https://www.researchgate.net/profile /SvenForke/publication/272491894_The_Aquatic_Climate_Archive_ Tracking_the_Rise_and_Fall_ of_ Ancient_Civilizations _Lessons_from_the_Past_for_the_Present_and_the Future/ links/54e636fd0cf277 664ff4a044/The-Aquatic-Climate-Archive-Trackingthe-Rise-and-Fall-of-Ancient-Civilizations-Lessons- from-the-Past-for-the-Presentand-the-Future.pdf\#page $=66$

Gee, Maggie (2019). The Ice People. Telegram, Telegrambooks. www.telegrambooks.com

Gluckman, Peter David (2020). "Anthropocene-related disease: The inevitable outcome of progressive nichemodification?" Evolution, Medicine and Public Health 1, 304-310. DOI: 10.1093/emph/eoaa042

Grech, Victor et al (2015). “The Deliberate Infliction of Infertility in Science Fiction.” World Futures Review 7, 1, 48-60. https://doi.org/10.1177/1946756715591166

--- (2012) “Gaia Beware: “Infertility in SF Due to Bioterrorism, Pollution and Accidental Iatrogenic Events." Vector 270, 26-30. https://www.um.edu.mt/library/oar/handle/123456789/25519

Haraway, Donna (2016). Staying with the Trouble: Making Kin in the Cthulucene. United States of America: Duke University Press.

Horner, Avril (2014). “Apocalypses Now: Collective Trauma, Globalization and the New Gothic Sublime." Trauma in Contemporary Literature: Narrative and Representation (eds. Marita Nadal and Mónica Calvo), Routledge, 35-50.

James, Phillys Dorothy (1994). The Children of Men. New York: Warner Books Inc.

Johns-Putra, Adeline (2018). "Maggie Gee's The Ice People (1998) and The Flood (2004): State of the Nation Cli-Fi." Cli-Fi: A Companion (eds. Axel Goodbody and Adeline Johns Putra), Oxford: Peter Lang ～(2018): 91-96.

--- (2017). "Borrowing the World: Climate Change Fiction and the Problem of Posterity." Metaphora 2, 1-16. $\quad$ https://metaphora.univie.ac.at/volume2-johns-putra.pdf 
Kaur, Harwinder (2016). “Dystopian Vision and the Hope for Humanity: P.D. James' The Children of Men." The Criterion 7, IV, 197-201. https://the-criterion.com/V7/n4/028.pdf

Kaya, Hilal (2021). "An Ecocritical Approach to the Book of Dede Korkut and Beowulf." Millî Folklor, 130, 31-43. https://dergipark.org.tr/tr/pub/millifolklor/issue/64594/690482

Kuznetski, Julia and Alaimo, Stacy (2015). "Anthropocene, Capitalocene, Plantatioocene, Cthulucene: Making Kin.” Environmental Humanities 6, 159-165. DOI:10.1215/22011919-3615934

"Late-night use of gadgets can cause male infertility: Study" (2021). Etimes, Retrieved January 5, 2021, from https://timesofindia.indiatimes.com/life-style/parenting/gettingpregnant/late-night-use-of-gadgets-can- cause-male-infertilitystudy/articleshow/80302210.cms\#: :text=According\%20to\%20a\%20recent\%20 study, sperm\%20and\%20fertility\%20was\%20studied.

Liboiron, Max (2013). "Plasticizers: A Twenty-first-century Miasma" Accumulation: The Material Politics of Plastic (eds. Jennifer Gabrys, Gay Hawkins, and Mike Michael), 134-149.

Luján, Saturnino et al. (2019. "Sperm DNA Methylation Epimutation Biomarkers for Male Infertility and FSH Therapeutic Responsiveness." Nature 9, 16786, 1-12.

MacLeod, Ken (2003). "Politics and Science Fiction." The Cambridge Companion to Science Fiction (eds. Edward James and Farah Mendlesohn), CUP, 230-240.

Malinda, Raj Rajeshwar (2021). “When sperm can't modify their proteins, their motors stop swimming." Massive Science. Retrieved September 2, 2021, from https://massivesci.com/articles/sperm-fertility-infertility- flagella/

Marques, Eduardo Marks de (2013). "I Sing the Body Dystopic: Utopia and Posthuman Corporeality in PD James's The Children of Men." Ilha do Desterro, 65, 29-48. DOI:10.5007/2175-8026.2013n65p29

Piguet, Etienne (2008). "Climate Change and Forced Migration." New Issues in Refugee Research, 113. Retrieved October 19, 2021, from http://citeseerx.ist.psu.edu/viewdoc/download;jsessionid=00404F2B803FAD DD1B8B1F27BDD5EA8C?doi=10.1.1.430.9162\&rep=rep1\&type=pdf

Sales, Kris, et al. (2018). "Experimental heatwaves compromise sperm function and cause transgenerational damage in a model insect." Nature Communications 9, 1, 1-11. https://doi.org/10.1038/s41467-018-07273-z

Sanzo, Kameron (2018). “New Materialism (s)” Critical Posthumanism. Retrieved September 1, 2021, from https://criticalposthumanism.net/author/kameron-sanzo/

Sepetoğlu, Selen (2014). Women and Eco-disasters in Maggie Gee's The Ice People and Sarah Hall's The Carhullan Army: An Ecofeminist Approach. Unpublished MA Thesis. Ankara: Hacettepe Univesity.

Wolfe, Cary (2010). What is Posthumanism? Minneapolis: University of Minnesota Press.

Yilmaz, Victoria Bilge and Kamalova, Raushan (2019). "An Analogy between Karakalpak Rites and Bakhtin's Carnival." Bilig, 91, 217-234. https://doi.org/10.12995/bilig.9109

Žižek, Slavoj (2010). Living in the End Times. London: Verso Books. 
